\title{
Skills acquisition and investments by Batswana migrants from southern Botswana to South Africa, 1970-2010
}

\author{
Wazha G. Morapedi*
}

\begin{abstract}
This paper focuses on migrant labour from southern Botswana to South Africa. The main thrust of this article is its emphasis on the positive contribution of migration to the migrants and their communities. It is argued here that although migrant labour has been blamed for having negative socio-economic effects in southern Botswana, just as in other parts of the country, it also contributed, and continues to contribute positively to the wellbeing of some households and their communities at large. Through the use of case studies from different villages in the district, the article demonstrates that poor, uneducated and unskilled young men who migrated to South Africa managed to accumulate and invest in agriculture and commercial enterprises and rose up the social ladder. In this area, migrant wages were critical in forming the basis of some enterprises, several of which are still flourishing. It also argues that some migrants acquired on-the-job skills which were later utilised productively when the migrants returned to Botswana. A similar study, but one which did not emphasise the acquisition of skills was undertaken by the author in the Bukalanga region of north-eastern Botswana in 2004.
\end{abstract}

Key Words: Botswana; South Africa; migration; agriculture; labourers.

\section{Opsomming}

Hierdie artikel fokus op trekarbeid van suidelike Botswana na Suid-Afrika. Die artikel poog om die positiewe bydrae wat migrasie vir migrante en hul gemeenskappe inhou, te beklemtoon. Ten spyte daarvan dat trekarbeid vir verskeie negatiewe sosioekonomiese uitwerkings in Botswana blameer is, word hier geargumenteer dat trekarbeid positief bydrae tot die welstand van sekere huishoudings en gemeenskappe in die breë. Deur die gebruik van gevallestudies in verskillende dorpies in die streek, gaan daar gewys word hoe arm en ongeskoolde jong mans wat na Suid-Afrika getrek het, dit kon vermag om in boerdery en kommersiële ondernemings te belê, terwyl hulle terselfdertyd ook die sosiale leer geklim het. Lone

* Wazha G. Morapedi is an associate professor at the University of Botswana. He graduated with an MA and PhD in Comparative History at the University of Essex in 1992 and 1989 respectively. He teaches Latin American, Botswana and Central African history. His research interests and publications are on migrant labour, agrarian history and the liberation struggle in Zimbabwe. 
wat uit trekarbeid verkry is, het die basis van sommige suksesvolle ondernemings gevorm. Hierdie artikel dui ook op hoe van die vaardighede wat trekarbeiders aangeleer het, later, na hul terugkeer na Botswana, produktief aangewend is. 'n Soortgelyke studie wat op die Bukalanga-streek in die noord-oostelike deel van Botswana fokus, maar waarin die aanleer van werksvaardighede nie beklemtoon is nie, is in 2004 deur dieselfde navorser onderneem.

Sleutelwoorde: Botswana; Suid-Afrika; verplasing; landbou; arbeiders.

\section{Introduction and historical background}

Labour migration is an international phenomenon that has been undertaken for ages. In different regions of Africa, labour migration was accelerated by colonial governments that accentuated regional inequalities within and between countries. In the early colonial period, the 1890s, young migrant labourers in the West African countries of Burkina Faso, Mali, Niger and Chad worked in the cocoa and coffee plantations of Cote d' Ivoire, the mines and cocoa farms of Ghana and the groundnuts fields of the Senegambia. The timber industries in Gabon and Equatorial Guinea and the palm plantations of Cameroon, recruited workers from rural areas of Nigeria and Senegal. In East Africa, migrant labourers from the hinterlands of Rwanda and Burundi worked in sisal, tea, cotton and sugar plantations of Uganda, Kenya and Tanzania. ${ }^{1}$

In southern Africa, labour migration from Botswana to South Africa began in the 1840s and 1850s, when Batswana, Basotho and Swazis went to work on the farms and at mission stations in the Cape Colony and other areas. The flow of men from Botswana and the southern African sub-region to South Africa increased when diamonds and gold were discovered in 1870 and 1886 respectively, stimulating the demand for wage labour. There were about 2135 Batswana working in the mines in 1870, and this number increased to 2571 in 1881. From the 1920s to the 1970s, the flow of men from Botswana to South Africa took a progressively upward trend, with annual recruits of 7314 in 1936; 10354 in 1956; 19150 in 1966; 39044 in 1976 and 40000 in 1978. ${ }^{2}$ Formal recruitment of mine labourers in Botswana was carried out by both the Native Recruitment Corporation (NRC) and the Witwatersrand Native Labour Association (WENELA). The number of Botswana migrants to South Africa declined significantly from the 1980s onwards. This decline was due to job cuts in the South African mining industry which largely affected non-locals. By this time there were also increased employment opportunities in Botswana.

1. See, A. Adepoju,"Internal and International Migration within Africa”, in J. Oucho et al., Migration in South and Southern Africa: Dynamics and Determinants (HSRC Press, Pretoria, 2006), pp 32-33.

2. J. Taylor, "Mine Labour Migration from Botswana to South Africa.", PhD thesis, University of Liverpool, 1979, pp 41 and 218. 


\section{Neglect of the socio-economic outcomes of migration}

Generally speaking, the historiography of migrant labour in southern Africa has been neglected in that it has not tracked the socio-economic outcomes of migrant labour in sending societies. The majority of studies have emphasised the exploitative nature of migrant labour, the low wages paid and the removal of male labour from agricultural activity. Such studies tend to make generalisations about the impact of absentee husbands and the social costs associated with migration. Furthermore, the dominant discourse in the study of migrant labour in southern Africa concerns itself with underdevelopment. Studies on migrant labour to South Africa emphasise the negative effects of the withdrawal of a large number of able-bodied men on their countries of origin; mainly the fall in agricultural production, dislocation of rural economies and the disintegration of families. They dwell on the exploitation of mine labourers, the effects of different ailments resulting from working down mines and the benefits that accrued to mining capital. ${ }^{3}$

These studies argue that migrants earned low wages, were exploited and served the interests of South African and British mining capital. Crop production and animal husbandry suffered in their areas of origin because of the withdrawal of ablebodied young males and in turn led to the exploitation of the labour of women. ${ }^{4}$ However, in a study based in South Africa, William Beinart provides fascinating cases of how the Mpondo migrants in the Transkei managed to invest in ploughs and cattle and improve production and how migrants acquired cattle by enlisting in migration to the mines. ${ }^{5}$ There are also a few studies in Botswana that discuss the socioeconomic gains of migration in former reserves or districts such as Ngamiland,

3. See, for example, C. Murray, Divided Families: The Impact of Migrant Labour in Lesotho (CUP, Cambridge, 1981); N. Moyo, "Migrant Labour and Underdevelopment in Southern Africa: Case of Botswana, Lesotho and Swaziland", Unpublished paper at Conference on Development and Politics of Liberation in Southern Africa, University of Zambia, 1978; D. Massey, "Labour Migration and Rural Development in Botswana.", $\mathrm{PhD}$ thesis, Boston University, 1980; C. Kerven, "The Effects of Migration on Agricultural Production", in C. Kerven (ed.), Migration in Botswana: Patterns, Causes and Consequences. National Migration Study, vol 3 (Government Printer, Gaborone, 1987); D. Kowet, Land, Labour, Migration and Politics in Southern Africa (Scandinavian Institute of African Studies, Uppsala, 1978); M. Wentzel and K. Tlabela, "Historical Background to South African Migration", in Oucho, et al., Migration in South and Southern Africa, pp 72-73.

4. K. Kobokobo, "Labour Migration and its Economic Impact on the North East District: The Case of Bukalanga, 1870-1939", BA dissertation, University of Botswana, 1982; M. Leepile, "The Impact of Migrant Labour on the Economy of Kweneng, 1940-1980", BA dissertation, University of Botswana, 1981; R. Letsatsi, "The Impact of Labour Migration on Botswana: A Case Study of Balete of Ramotswa, Bangwaketse of Kanye and Bakgatla of Mochudi, 1900-1970", BA dissertation, University of Botswana, 1984; N. Kubanji, "The Impact of Labour Migration on the Tutume Sub-District: A Case of the Villages of Tutume, Sebina, and Maitengwe", History Research Project, University of Botswana, 1992.

5. W. Beinart, "Labour Migrancy and Rural Production: Pondoland c. 1900-1950", in P. Mayer (ed.), Black Villagers in an Industrial Society (OUP, Cape Town, 1980). 
Kweneng and recently, the north east region. In his work on Botswana generally, Isaac Schapera observes:

Labour migration ... has made it possible for even the lowest commoner to earn money with which to purchase trade goods. This has helped to break down the correlation of rank and wealth, and given more scope for individual enterprise in the attainment of riches". ${ }^{6}$

Similarly, in Ngamiland for instance, migrant labour did not undermine peasant agriculture, but instead complemented it and enabled many young men to accumulate savings quickly and marry younger than they had done previously. The payment for migrant labour was also higher than work done for peasant employers and migrant wages increased steadily after World War II, reaching a peak of $€ 45$ a year by 1954 . Such work offered higher remuneration to young uneducated and unskilled men than payment they could earn locally. This was also a period when there were difficulties in cattle farming due to Tse-tse fly infestation and the tightening of tax collection. ${ }^{7}$ These two factors meant that it was difficult to make investable savings from cattle farming and the tightening of taxation eroded investment opportunities even further. Therefore, migration, in addition to equipping Batswana with skills, enabled them to save and invest in gainful ventures.

The present article attempts to delve into the largely unchartered path of migration which reveals post-migration developments in southern Botswana showing gains in wealth and social status from the late 1970s to the present. The article argues that migrant labour in Botswana should be placed in the general context of British rule in Botswana. With Britain's tenacious application of its policy of neglecting the development of Botswana, ${ }^{8}$ migrant labour offered the only alternative for accumulation for many poorer households for some time after independence. With still very little tangible development and employment opportunities, persistent droughts and non-existent marketing outlets for agricultural produce, migrant labour was the only option for many to establish themselves economically and socially. After the attainment of independence in 1966, Botswana

6. I. Schapera, Migrant Labour and Tribal Life: A Study of Conditions in the Bechuanaland Protectorate (Heinemann, London, 1947), pp 161-162.

7. See Schapera, Migrant Labour and Tribal Life, pp 161-162; B. Morton, "A Social and Economic History of a Southern African Native Reserve: Ngamiland 1890-1966”, PhD thesis, Indiana University, 1996, pp 199- 227; J. Solway, "Socio-Economic Effects of Labour Migration in Western Kweneng", in C. Kerven (ed.), National Migration Study: Papers Presented at a Workshop on Migration Research, Gaborone, March 1979, pp 123-125; W. Morapedi, "Migrant Labour and the Peasantries of Bechuanaland Protectorate, 1930-1966", Journal of Southern African Studies, 25, 2 (1999), pp 199204.

8. Massey, "Migrant Labour and Rural Development in Botswana", pp 100-101; J. Parson, Botswana: Liberal Democracy and the Labour Reserve in Southern Africa (Boulder, Lynne Reinner Publishers, 1984), pp 25-26 and 33; L. Picard, The Politics of Development in Botswana: a Model of Success? (Lynne Reiner Publishers, Boulder, 1987), p 96. 
began to experience some tangible developments from the mid-1970s after the discovery and exploitation of copper/nickel and diamonds at Selibe Phikwe and Orapa respectively. But mining, especially the lucrative diamond mines did not employ many unskilled Batswana and hence many continued to work in South Africa.

Archival sources are largely silent on the positive aspects of migrant labour in Botswana except for a few reports from the Bakwena, Bangwato, Batlokwa and Bakgatla reserves earlier in the 1930s. The reason for this could be that in the 1930s, the country's economy was in a bad state. There were droughts, coupled with the effects of the cattle weight restriction measures imposed by South Africa from 1924. The Pim Commission Report of 1932 painted a desolate situation in Botswana and colonial authorities seem to have concentrated on reporting on this dire situation. During this period, the number of migrants to South African mines was on the rise and the negative effects of the withdrawal of many young able-bodied men was blamed for the deteriorating economic situation, especially in the cattle industry which was the lifeblood of the country.

With these circumstances in mind, for the most part this study utilised oral, secondary sources and participant observation, which involved visiting existing homesteads and business complexes. Using case studies of various former migrants in southern Botswana, the article shows that indeed a number of people from poor households used migrant wages and skills acquired outside the country to set up businesses, acquire cattle and establish themselves. This became the basis of their livelihoods today. These benefits did not only accrue to individuals, but have trickled down to the larger communities and hence uplifted the living standards of many. The oral testimonies from Moshupa, Kanye, Gabane and Thamaga villages in southern Botswana illustrate the positive effects on migrant labour for individuals and their communities after independence. In all, seventy former migrants were interviewed in Kanye, Moshupa, Thamaga and Gabane. Three group interviews were also conducted in Kanye, Moshupa and Thamaga. There were eight people in the Kanye group; six in the Thamaga group; and seven in the Moshupa group. All group members were aged sixty years and above. Although it is difficult to state clearly how representative the sample is because statistics from individual villages are not available, it would appear that the responses, together with those from former migrants, suggest that some plausible conclusions can be reached.

\section{Migrancy in Botswana and its benefits}

Most studies on migrant labour in Botswana have neglected certain crucial aspects on the positive contributions that this form of labour has made to the socio-economic development of different communities in terms of remittances and deferred pay. Deferred pay means the amount a migrant is entitled to collect from the relevant recruiting agency on return at the end of the contract when all the stipulated advances have been deducted. Remittances are those monies sent home voluntarily to designated individuals. ${ }^{9}$ Migrants also brought back money and other items. Some

9. Moyo, "Migrant Labour", p 10. 
testimonies were provided by those who worked in industries outside mining. They managed to save some money and then invested wisely when they arrived back home.

This section seeks to answer some crucial questions on the role that migration plays in the development of sending communities. In her study titled Migrant Labourers, Sharon Stitcher poses questions on the cumulative effects on rural economies when the men are involved in prolonged large-scale migrancy. ${ }^{10}$ These questions include whether migrancy might contribute to rural development; whether it could provide a new inflow of cash for investment in agriculture and commercial enterprise; or whether it was a means of warding off rural starvation or at worst a system which undercuts rural progress. Stitcher wondered whether migrants could ever accumulate and become a new bourgeois class or whether they remained forever trapped in the cycle of oscillating migrancy. ${ }^{11}$ These are some of the questions that this study will address.

There is also a need to examine migrant labour in the southern African arena in relation to the New Economics of Labour Migration (NELM) theory. According to this theory, the range of migration and remittance impact can be divided into two extremes. The first of these is the "developmentalist" extreme, which argues that the decision to migrate is part of a family strategy designed to raise income, obtain funds to invest in new activities and insure against income and production risks. It further holds that remittances in turn produce a development dynamic by cutting loose production and investment constraints faced by households in poor developing countries. The second extreme is that of the "migrant syndrome", which maintains that lucrative migration activity drains the labour and capital from migration sending areas and has a negative effect on local production of tradable goods. Because migration is a self-perpetuating process, after some time villages, regions and even countries depend on migration and become labour exporting. ${ }^{12}$ These theories will be tested in the southern Botswana/South Africa context by using empirical data and other relevant variables in the area.

Although the positive role of migrant labour to rural communities in Botswana has been largely overshadowed by an emphasis on the negative effects, Schapera's study in the 1930s and 1940s has revealed that migrant labour was the single most important source of cash in the country. He wrote that there were four main sources of income in the country between 1938 and 1947. These were the sale of agricultural produce, which earned $£ 242,500$, which was $31.5 \%$ of the total income. Employment inside Botswana brought in $£ 135,800$ translating to $7.7 \%$. Allotments from army pay amounted to $£ 361,000$ which was $7.9 \%$ and employment outside the territory

10. S. Stitcher, Migrant Labourers (Cambridge University Press, Cambridge, 1985), pp 2526.

11. Stitcher, Migrant Labourers, p 25.

12. J. Taylor, "The New Economics of Labour Migration and the Role of Remittances in the Migration Process", International Migration, 37, 1 (1999), p 64. 
brought in $£ 330,000$ which was $42.9 \%$ of the total income. ${ }^{13}$ If these statistics are reliable, then they show the crucial importance of labour migration to the economy of Botswana in that period. On the relevance of migrant labour to Tswana livelihoods, Schapera notes that the "export of labour has become an outstanding feature of the Tswana economy. Without the income that it provides, the Tswana could not possibly maintain their present standard of living."14 According to Schapera, about half the annual expenditure by Batswana was met through income from migration. Batswana working on the country's white farms earned about $£ 54,000$, whilst migrant labourers accumulated $£ 333,000$ in the form of cash or goods. These two sources together contributed about $54 \%$ of the total income of the country. ${ }^{15}$ Generally, in the 1930 s to the late 1960s, migrant labour remained one of the main sources of income in the country, coming second only to cattle farming.

Some studies carried out in post-colonial Botswana until the mid-1980s, highlight the positive contributions of migrant labour to the country, although more emphasis is placed on how it undermined the socio-economic system and underdeveloped rural societies. ${ }^{16}$ In the 1970s, it was noted in a Census Report that "much of the workforce is employed abroad and the tradition of migrant labour does ... mitigate the effects of economic hardship at home".17 As late as the 1970s, Carol Kerven revealed that migrant labour wages played a crucial role in the accumulation of cattle and provision of education to Batswana children. Migration of the rich in society, those with large cattle herds, allowed this stratum of society to maintain and increase their herds and to re-invest some of their mine savings (i.e. from migrant labour) and capital from the sale of cattle into the education of their children. These educated children would then be able to secure salaried employment in the modern sector of Botswana's economy and continue with the accumulation of cattle in the rural sector, consolidating the superior position held by this segment of the society.

In the middle sector of society, migrant labour allowed members of lower standing to enter the upper stratum of the cattle-owning elite. Although the position of those in the middle sector tended to be somewhat unstable, migrant labour provided this group with an escape from poverty and opportunities to penetrate the ranks of the upper level. ${ }^{18}$ In his study, David Massey discovered that half of the mineworkers who owned cattle acquired them through their incomes from the mines. He also established that $75 \%$ of families managed to plough in the $1976 / 1977$ season

\footnotetext{
13. Schapera, Migrant Labour and Tribal Life, p 161.

14. Schapera, Migrant Labour and Tribal Life, p 121.

15. Schapera, Migrant Labour and Tribal Life, pp 121-130.

16. Solway, "Socio-Economic Effects", pp 38-39; C. Kerven, "Underdevelopment, Migration and Class Formation in the North East District of Botswana", PhD thesis, University of Toronto, 1977", pp 60-61; Massey, "Labour Migration and Rural Development.", p 280.
}

17. Botswana Census Report, 1971, pp 33-35.

18. C. Kerven, "Introduction", in "National Migration Study", Paper Presented at a Workshop on Migration Research, Gaborone, 1979", p 5. 
and that some families hired tractors. This is an indication that migrant earnings could be used to hire draught power. ${ }^{19}$

Labour migration played a crucial role in bridging the social stratification gap. Jacqueline Solway's study on Kweneng district reveals that migrant labour offers poorer members of the society the opportunities for upward mobility or to break out of the client- dependency on the wealthier elite. Solway further notes that migrancy resulted in widespread cattle distribution in the Kweneng area of Botswana in the late 1970s and this was because it removed people from the traditional structure which had impediments to cattle accumulation, especially by the poor. With migrancy, one could acquire and accumulate property, especially cattle without any assistance of one's relatives. Solway adds that "prior to labour migration, cattle ownership was concentrated among the elite. The poor were dependent upon the rich and offered their labour in exchange for food". Allowing the poor access to property was certainly not a negative aspect of labour migration. ${ }^{20}$ Cattle were, and to some extent still are, an important source of wealth in Botswana and the migrant labour system provides the means to acquire cattle.

Studies that have emphasised the underdevelopment of Botswana as a result of labour migrancy to South Africa have for the most part neglected to recognise the precarious economic situation in Botswana during the colonial period and for some years after independence. These studies, and here with reference to the southern parts of the country, did not take into account other factors which made general subsistence and opportunities for any form of accumulation and upward social mobility almost impossible for poorer households. Colonial Botswana was one of the most neglected by the mother country. Very little development took place in the colonial period and opportunities for wage employment were limited. The role of migrant labour in the socio-economic lives of Batswana cannot be fully appreciated without placing these issues into perspective. This resonates well with John Taylor's observation that the impact of labour migration and remittances should be assessed relative to what migrant sending economies would have looked like without migration. ${ }^{21}$ Immediately after independence in 1966 and for the two decades that followed, it was not easy for unskilled Batswana to find work locally that was comparable to mine labour.

Writing generally on migrant remittances and the way they empowered rural communities in southern Africa, N.J.H. Penny states that:

The means which makes this transfer of welfare possible is the repatriated earnings of the migrant. Miners repatriate their earnings in three basic forms, namely as money and goods sent home during the contract period, as savings by

19. Massey, “Labour Migration”, p 167.

20. Solway, "Socio-Economic Effects", p 41.

21. Taylor, "The New Economics", p 99. 
deferred pay arrangements, and as money and goods returning with the migrant at the end of his contract. ${ }^{22}$

A study conducted on 1200 miners in southern Africa shows that $100 \%$ of all those interviewed remitted at least some of their total wages for the duration of their mining contracts. ${ }^{23}$ Cersten Sander and Samuel Maimbo have also emphasised the significance of such remittances by stating that:

... remittances are of crucial economic importance to many African households and countries of origin and nations, helping to stabilise irregular incomes and to build human and social capital. Remittance receivers are typically better off than their peers who lack this source of income. ${ }^{24}$

For a country in Botswana's position then, remittances by migrants were a positive development. The general positive effects of migrant labour on Botswana society in the period under study has been summarised by Kerven in her assertion that: "Mine labour migration forms one of the major sources of income and employment in the lives of many Batswana families. Its social and economic effects permeate the society, and have been present for a number of generations." These include the skills acquired whilst working in South Africa. ${ }^{25}$

\section{Migrants from southern Botswana: The acquisition of skills and investments}

Migrant labour played a crucial role in the livelihoods of some households in southern Botswana. Interviewees, mostly former migrant labourers and their families maintain that with the proceeds of their labour they have managed to uplift themselves and acquire property such as cattle, and some have established businesses which have grown to become household names in various villages. Even non-migrants attest to the fact that migrant labour transformed the lives of many households. Throughout the 1970s and 1980s, Botswana's education system levied school fees on parents. The oral testimonies reveal that migrant remittances and deferred pay play a crucial role in the payment of school fees and today many people from the area, as a result of receiving a good education, hold well-paid positions of employment. The case studies illustrate some productive skills and items acquired and ventures undertaken by migrants using their wages and the way such funding contributed to the wellbeing of rural households.

Former migrants, their spouses and relatives in southern Botswana provided accounts of how migrants invested their savings from monies received from South

22. N. Penny, Migrant Labour and the South African Gold Mining Industry: A Study of Remittances (UCT, School of Economics, n.d.) p, 9.

23. Penny, Migrant Labour, p 12.

24. S. Maimbo and C. Sander, "Migrant Labour Remittances in Africa: Reducing Obstacles to Developmental Contributions", Africa Regional Paper Series, No. 64, World Bank, Washington DC, p 1.

25. C. Kerven, "Botswana Mine Labour Migration to South Africa", in C. Kerven (ed), National Migration Study (Central Statistics Office, Gaborone, 1979), p iv. 
Africa. Some of the migrants loaned out their cattle to those with none, using the mafisa system, and this enabled those who initially owned no cattle to build up herds. Although the mafisa system has been described as exploitative, it had the positive effect of enabling the poor to acquire cattle and cultivate crops, thus sustaining livelihoods. Many of the informants also mention the fact that some migrants built herds which then enabled them to pay lobola (bride price). ${ }^{26}$ The payment of school fees was a burdensome task in the 1970s and 1980s, and some eligible children could not go to school because parents could not afford the fees, or had to drop out of school. However, the oral testimonies reveal that many children were indeed educated through migrant earnings and some even went on to acquire university education. Today these Batswana occupy top positions in government and the private sector. This is one of the hidden positive aspects of migration that scholars of migrant labour in Botswana have neglected, and one that proved to be a critical investment since those who received education now constitute a pool of the country's skilled resource base. ${ }^{27}$ In his study, Aderanti Adepoju identifies hidden positive ways in which remittances contributed to livelihoods in south eastern Botswana. He states:

Migrant remittances, an enduring linkage between migrants and home family, community and national levels help sustain and enhance livelihoods of poorer family members in paying education fees for siblings and basic services, healthcare in particular, investing in real estate and taking steps to enhance agricultural production. ${ }^{28}$

Oral testimonies below by Ben Thage from Kumakwane village and Thebe Matlhodi from Kanye, show how migrants managed to build herds and pay bride price. Most importantly, the two cases illustrate the use of migrant savings in education through the payment of school fees.

Ben Thage began working in South Africa in 1977 and left in 1993 having worked at an underground section of railway, repairing pipes at Carltonville and Thabazimbi. Thage managed to progress to the position of foreman and although he was not paid much, by the time he left, he received R4000 to R5000 per month and some additional bonuses. At first Thage did not want to buy cattle, but in 1995 he bought three cows, intending to pay bride price. In 1996 he bought a herd of eight cattle and paid bride price with them, retaining the original three; he then started a

26. P. Mgadla, "The Dikgosi in a Traditional Setswana Setting", in W. Edge and M. Lekorwe, Botswana: Politics and Society (J.L. van Schaik, Pretoria, 1998), p 8. Mafisa were cattle loaned to another person for that individual's benefit. He was allowed to milk the cattle and use them as draught animals for crop cultivation. The owner of the cattle might give the one who was taking care of them a heifer or two as a sign of appreciation. In this way the person who had loaned the cattle could gradually build up a herd for himself.

27. This was also found to be the case in the Bukalanga area of north eastern Botswana, see W. Morapedi, "Investments from Migrant Labour in Central Bukalanga of the Central District of Botswana, 1934-1985", Botswana Notes and Records, 44 (2012), pp 34-44.

28. Adepoju, "Internal and International Migration", p 31. 
moraka (cattle farm) in 1997. Thage sold one cow to pay for the transport to take his cattle to a cattle post in Salajwe; by this time the herd had increased to thirteen. He then went on to buy a mini bus from an auction at Wade Adams for P17000.00 with some of the money from his wages. By then Thage also had two cars, a Datsun Pulsar and a Nissan Skyline. He sold the two cars and seven months later bought a second mini bus and later a third one. Currently, the man owns two mini buses. His wife has been working as a teacher. Thage has purchased a residential plot at Kumakwane where he has built a very big house and he also has a $4 \times 4$ Hilux van which he uses to help people in the village. He employs three people in his mini bus business and two others as herdsmen at his cattle post. His herd has increased to just below 100 head of cattle, a sizeable one. Thage has also built a second big house at Tloaneng, about 30 kilometres from Gaborone and his two children have completed their tertiary education, one at the University of Botswana and the other at the then Botswana College of Agriculture (BCA). The two are now fully employed. Thage's parents used to stay in a mud house, but he has built them a modern brick house with a floor and a tiled roof, fitted with a bath and running water. He admits that some of his less successful counterparts, because of their poor planning of their finances do not like him. ${ }^{29}$

Another migrant, Thebe Matlhodi, a resident of Kanye, was also interviewed. He testified that in addition to investing in education through the payment of school fees, some migrants, as noted by Adepoju, managed to invest in real estate and retail businesses. A former migrant worker, Matlhodi did not finish his standard seven class at school but went to work from 1977 to 1999 for various construction companies in South Africa, such Jerry \& Sons and Warner. He was a malaisa (labourer) for two years but later became a bricklayer, and also a roofing and tiling expert and plumber. Matlhodi learnt these skills by observing others - they showed him how to do these things and he was a quick learner. He doesn't have any certificate, but has good references from his former employers (companies).

While Matlhodi was working, he sent money home to pay for his younger brother and sister's school fees at Seepapitso Secondary School in Kanye. They have now finished schools and the one is a teacher, while the other is the matron at a local hospital. He bought cattle and later built a general dealer shop and liquor restaurant, both of which are still in business. Matlhodi employs four people in these enterprises. He owns a big yard with a four-bedroomed house and also has two smaller houses for guests. Matlhodi also has a construction company called Majakathata and he has built many houses in Kanye and nearby villages. He has also undertaken community tenders such as halls, the Village Development Committee (VDC) houses, nursery schools, churches and has been sub- contracted by bigger companies to build residential houses. He is proud of the fact that he has won big tenders of up to P500,000 funded by banks and owns many cattle and goats at his cattle post, where he employs two herdboys. He has two houses, one in Block 9 and another in Mogoditshane, near Gaborone, which he rents out. So, although Matlhodi is also a 
farmer, his construction company and other businesses, including the rented houses means that his livelihood and those of his siblings are not dependent on agriculture. ${ }^{30}$

According to Taylor, most studies carried out on remittances argue that they are consumed rather than invested; that they are not used productively. This view is based on arbitrary definitions of "productive investment". For instance, schooling is often left out of definitions of productive investment, probably because expenditure on educating family members are not seen as creating direct immediate employment and income linkages in migrant sending economies. ${ }^{31}$ However, in this study interviewees mentioned the payment of school fees for their children's education and indicated that education was indeed productive investment; educated family members contributed later to the sustenance of their family households.

There is evidence that some early businesses such as general dealers, liquor restaurants and bars, buses, and mini buses in the transport sector were started by returning migrants in the 1980s and early 1990s. These men were also some of the first to build big modern dwellings with brick walls and tiled roofs. These were worthy investments. Several people in the community were employed in these ventures and some of these businesses are still in operation. Oral sources indicate that some migrants, especially those who worked in factories and in the construction industry, learnt skills such as painting, plastering, bricklaying, plumbing, electrical work and welding. Upon returning to Botswana, many of these labourers employed these skills and some of them started up their own companies, while others were hired as artisans who worked for individuals or local companies. ${ }^{32}$ Migrancy provided these Batswana with some life-long skills which enabled them to be self-employed. These skills were, and are still lacking and there is a critical shortage of skilled people, especially in the rural areas.

Evidence from the case studies also accords with the "developmentalist extreme" theory espoused by Taylor. This theory postulates that migration is a family strategy designed to generate income and funds to be invested in new ventures and insure against income and production risks. ${ }^{33}$ In southern Botswana, these new ventures cushioned households against risks in the predominantly risky agricultural economy of the country. Profits from such ventures were then used to buy foodstuffs like mealie-meal and the staple food, sorghum, in years of drought when yields from agriculture were low or non-existent. At such times the profits were also used for paying school fees at a time when cattle were in a poor condition due to the drought and could not be sold. This aspect of labour migration has also been noted in a general context by Adepoju in his assertion that: "Migrants can acquire skills and some capital that can be productively invested in ventures back home, which boost

30. Interview with Thebe Matlhodi, conducted by author at Kanye, 17 June 2014.

31. Taylor, "The New Economics", pp 72-73.

32. Group interviews conducted by the author with a group of Ipelegeng workers in Moshupa, 13 June 2014; three elderly men and an elderly woman in Kanye on 11 June 2014; and three elderly men in Thamaga on 13 June 2014.

33. Taylor, "The New Economics", pp 72-73. 
local productivity."34 This claim is backed by the oral testimonies of James Kefitlhile and Thabo Morale of Gabane and Thamaga villages respectively, and by other testimonies mentioned in this article.

In 1989, Kefitlhile went to work in South Africa where he was employed by a contracting company as a labourer, laying water pipes. He later became a knowledgeable plumber who worked for many individuals and organisations. He was not even literate and had great difficulty writing his name. When Kefitlhile started working, he earned R400 a month, but by the time he left, he was earning R3000 because of some promotions. This Motswana man bought a heifer with his wages when he came back home on holiday and he also exchanged some of his cattle for a vehicle.

After returning from South Africa, he continued with plumbing work and worked on projects for construction companies and individuals which paid him handsomely. With the proceeds, he managed to buy three mini buses with his wages and later employed three drivers. In the process, Kefitlhile helped these drivers because now they run their own mini bus businesses. His policy was that he opened bank accounts for them and paid them through the bank. This enabled them to save and later buy their own combis; they are now plying the Gabane to Gaborone route. Kefitlhile also bought a Toyota Hilux van which he used to carry goods to the cattle post and often helped others with transporting their loads. He also owned a car which was used by his wife. He still has a cattle post where he employs two herd boys and he has about seventy to eighty head of cattle although he admits that his herd has suffered as a result of the drought. Kefitlhile has built a very large, modern house at Gabane and another at Kumakwane. He is married with two children, both of whom are still at school, one in Form 3 and the other in Standard 7. His combi businesses have been doing well. He too was critical of some of his counterparts who were previously migrant workers and he maintained that they were poor because they did not invest wisely. ${ }^{35}$

Another former migrant, Thabo Morale from Moshupa began working in 1978 after attending school until Standard 7. In 1999 he went to work in South Africa. He first worked for a construction company called Buildco and then joined Wallis Construction. They were doing building and installing electricity and plumbing in Johannesburg and the surrounding areas. The companies were also laying water pipes and connecting residential houses, industries and shopping complexes to available services. Buildco had many workers but about 15 of them worked with one white man who was the foreman and his two coloureds assistants.

Morale's task was to assist them with cutting and connecting water pipes, fitting taps, geysers etc. They were taught which pipes were used in different situations and how they should be fitted properly. He watched closely and after some time he was also allowed to do some fitting work; there were even occasions when

34. Adepoju, "Internal and International Migration", p 39.

35. Interview with James Kefitlhile, conducted by the author at Gabane, 15 June 2014. 
workers were left alone to do work. In other words, Morale learnt his plumbing skills on the job. His payment was gradually increased; he started at R400 a month and this went up to more than R3000 when he left. This payment, Morale pointed out, was far better than the wages earned by his counterparts in Botswana. He started buying cattle in 1983 and by 1999 when he left work, he had more than thirty head of cattle. He managed to buy two second hand mini buses and a van while still working. Before he Morale left Johannesburg, he bought a second hand tipper truck which he used later to supply people back home with sand for building. Back in Botswana, using his earnings wisely, he later ran five mini buses and one bigger bus and he employed a total of twelve people. He also owned a tuck shop and a bottle store in Moshupa where he employed two more workers. He is still working on local tenders, and is involved in community projects in Thamaga, Moshupa and Kumakwane.

Morale still does plumbing at places like Gaborone and surrounding villages. He has helped hundreds of people in the surrounding areas and has also done work for organisations like churches, crèches, shops and bars etc. He employs three local casual labourers who help him when he has demanding tenders. He is married with one child who has finished at Molepolole College of Education and works as a teacher. Morale has a big yard with a three-bedroomed house; there are two other dwellings on the property and the compound is walled. He has bought and built houses in two big compounds measuring 40 metres by 40 metres in Gabane and rents them out to people working in Gaborone. He employs two cattle herders to look after his cattle which number about ninety. He has been selling his cattle to the Botswana Meat Commission and local butcheries in the past years. He intends going into the bus industry in the future. He has also secured a ploughing field and wants to drill a borehole soon. ${ }^{36}$

It is clear from the above testimonies that these former migrant workers have not only established themselves financially but have also empowered other Batswana. Kefitlhile is perhaps the best example because he made sure that the men he employed as drivers were able to start their own businesses, employing more people in the process. The employment of herd boys, attendants at general dealer shops, and other workers in the construction industry by former migrants also boosted local productivity and the economy, and therefore gives credence to Adepoju's claim that the skills and capital acquired by migrants can potentially be invested productively in ventures back home and thereby boost local productivity. The income and funds generated by these respondent were invested in new ventures and were a hedge against income and production risks in line with "developmentalist extreme" theory espoused by Taylor.

The oral testimonies also show examples of the way migrants have acquired skills and invested the proceeds of this labour, which provides answers to questions posed by Sharon Stitcher and John Taylor's new economics of labour migration theory. Former migrants also settled down and engaged in gainful activities and for the most part the areas they came from are no longer fully dependent on exporting

36. Interview with Thabo Morale, conducted by the author at Thamaga, 15 June 2014. 
labour to South Africa. This is also because the locals employed by former migrants did not have to migrate to South Africa to find work.

What also emerges from the oral testimonies is that people from the poorer section of society managed to acquire or accumulate and move up the social ladder, and that for some families this laid the foundation upon which their present wealth was built. This has also been noted by Kerven in the case of Botswana in her statement that:

\begin{abstract}
Mine labour is open to all unskilled men, regardless of their stratum in society; opportunities for accumulating cattle were opened up to those who might never have had access to cattle, in the pre-migration days. Wealth, in the form of cattle, was formerly concentrated in the hands of the elite, defined along kinship lines; with labour migration, non-elite could gain access to wealth, without having to have the necessary kinship ties. ${ }^{37}$
\end{abstract}

The consolidation of migrant wages into income generating businesses which are still in business today and the acquisition of cattle, run contrary to the second extreme of the new economics of labour migration - the "migrant syndrome" which postulates that attractive migration drains exporting areas of capital, and labour migration becomes a self-perpetuating process which leads to villages, regions and countries becoming labour exporting and dependent on labour export.

The oral testimonies provided in this study show that after some years in South Africa, astute migrants were able to establish themselves in Botswana and settle down in their home country rather than migrating south. They provided employment to other Batswana in their villages and hence this counteracted labour migration, becoming a self-perpetuating process. Migrants who provided oral testimonies in this article came from poor households and did not have the necessary kinship ties to own cattle. However, by astute management of their migrant savings, they managed to acquire cattle, which they may never have been able to do had they not taken this step. This gives credence to Kerven's conclusions.

In her study, Stitcher postulates that the strategy of using migrant labour to generate cash and invest in agriculture does not appear to have succeeded in most of rural Africa. She claims that migrant remittances were largely used to maintain existing levels of living in rural areas rather than stimulating agricultural development. This is because migrants are rational economic actors who come from areas of inherently low development potential. It appears generally that migrant labour did not provide the basis for a self-sustaining rural development independent of other changes in the rural environment. On the other hand, Stitcher notes that "migrancy can be a successful strategy ... for individuals operating in favourable contexts". ${ }^{38}$ Stitcher's observation is critical in the case of southern Botswana. Here, to a large extent, migrancy provided a basis for self-sustaining rural development.

37. Kerven, "Introduction", p 81.

38. Stitcher, Migrant Labourers, p 46. 
This is because it provided migrants with cash to purchase agricultural implements and draught power (cattle) which had the potential to increase areas under cultivation and crop yields, especially in seasons when there were good rains. Although cattle were often decimated by droughts and diseases, some migrants built the nucleus of a herd from cattle purchases. Investments in cattle led to the growth of herds which were sold and businesses such as general dealers, liquor restaurants and farms were established. Investment in other sectors besides agriculture also shows that the rural economy was stimulated and employment created by businesses which were independent of agriculture as shown by the oral testimonies cited above.

In southern Botswana, Stitcher's contention that migrancy can be a successful strategy for individuals operating in favourable environments has been validated because migrants who came from densely populated villages have become successful businessmen from their earlier investments through migrant earnings. This proves that migrant labour in the area provided a new inflow of cash for both agricultural development and commercial enterprise. The emergence of several big businessmen in this area, people who initially started with migrant wages, indicates that to a certain extent migrancy created a new "rural bourgeoisie". N. Penny has rightly pointed out that "... to accumulate significant domestic resources such as land, livestock, fertiliser, fencing, ploughing teams, trading stores etc. requires migrant labour". ${ }^{39}$ This assertion is largely true for southern Botswana as exemplified by the oral testimonies. Taylor has also observed a similar situation in Mexico. Here, in the province of Guadalajara, remittances have been critical in capitalising migrant owned businesses. A survey in this province found out that $21 \%$ of the migrants surveyed started their businesses through migrant wages, and in three other rural communities it was found that in 1990, 61\% of businesses were funded with earnings from migrants in the United States. ${ }^{40}$

While remittances and employment opportunities to migrants may be relatively unimportant in national terms, they are crucial to some sectors of the population. ${ }^{41}$ Writing about the general situation of mine labour and its vitality to Botswana in the 1970s, Alan Whiteside relates that the increase in mine wages in the 1970s, and the high risk of drought have revealed the vitality of migration in the country. Migrant earnings enabled households to invest, and in the 1970s, about $30 \%$ of the disposable income of miners was spent on agriculture. In 1983, this spending was estimated to be P9.7 million. ${ }^{42}$ In 1979, Botswana had 19985 migrants and they remitted P10, 862, 750. During this period, oral sources reveal that wages were better in the mines and migrants bought bicycles which they later exchanged for heifers. Generally, it has been observed for the country in the early 1970s that "much of the workforce is employed abroad and the tradition of migrant labour ... mitigates the

39. Penny, Migrant Labour, p 32.

40. Taylor, "The New Economics.", p 731.

41. A. Whiteside, Some Aspects of Labour Migration between the Republic of South Africa and Neighbouring States: Part II, Economic Implications, (HSRC Press, Pretoria, 1986), p 41.

42. Whiteside, Some Aspects of Labour Migration, p 41. 
effects of economic hardships at home".43 The case studies and the foregoing arguments show that indeed migrant labour contributed to rural development because it provided a new cash inflow for investment in agriculture and commercial enterprises.

In the 1980s, migrant wages remained vital for the poor in Botswana. They provided about $75 \%$ of cash earnings of the poorest people. Such wages provided the only escape route from the poverty trap, enabling the migrants to begin accumulating wealth. The proceeds of labour on the gold mines ranked behind earnings from diamond mining, while local meat and meat products and copper nickel followed as the country's most valuable export in 1983.44 In the early 1980s, many people from southern Botswana still worked in South Africa. Many young men came back from South Africa and bought cattle as well as building themselves permanent and modern houses of brick and corrugated iron, and also started commercial businesses.

In 1984, there were about 26433 Batswana registered as working in South Africa. Of these, 19757 worked on the mines. Generally, the majority of these were from the poorest families in the rural areas. Commenting on these developments, Whiteside writes that "for over 25000 workers, the opportunity for migration to South Africa has been crucial to their way of life and the only chance to begin the process of accumulation". ${ }^{45}$ In stark contrast, Nelson Moyo argues that migrants used very little of their earnings to improve agriculture. He contends that most of the cash appears to have been used to purchase consumer goods such as food, clothes, furniture, bicycles, radios, etc. and that the impact of migrant's wages on the economies of the Botswana, Lesotho and Swaziland was minimal. He goes on to say that in Botswana, the deferred pay was frequently "squandered by the migrant at the pay points which are frequently surrounded by brewers of traditional beer, retailers of modern beer and prostitutes". ${ }^{46}$ Some of Moyo's assertions are valid and interviewees also mentioned that some migrants have wasted their savings on unproductive undertakings. But it would appear that this type of migrant labourers were in the minority and their failure to invest should not be blamed on migrancy, but on their personal conduct. There is no doubt that a sizeable number of migrants from Botswana invested in productive ventures and were able to keep their families afloat during difficult times.

Even in the 1970s and 1980s in Botswana, it has been revealed that if a household had to meet its basic Poverty Datum Line requirements from the sale of cattle, then it would have to dispose of five head of livestock per annum. In 1976, only $5 \%$ of rural families had more than 51 beasts. This shows that the selling of cattle to meet basic requirements was not a viable option for the majority of households. ${ }^{47}$ This then meant that migrant labour remained the major source of livelihood for many Batswana.

43. Botswana Census Report, 1971, pp 33-35.

44. Whiteside, Some Aspects of Labour Migration, p 42.

45. Whiteside, Some Aspects of Labour Migration, p 45.

46. Moyo, "Migrant Labour", p 16.

47. Kerven, "Introduction", p 7. 
Migrant labour in southern Botswana should be viewed in the general context of wage employment opportunities in colonial and post-colonial Botswana. Even in the 1970s and 1980s most job opportunities in government, the largest employer, were not for the unskilled labourer. On the other hand, in 1976 and 1977, migrant labour was one of Botswana's major exports to South Africa because of incomes accrued by migrants. The crucial input of migrants to Botswana's economy is shown by the fact that, "Total earnings by Batswana citizens in South Africa were almost as much as earnings by Batswana citizens within Botswana". It is difficult to measure the amount of money and goods that entered Botswana from non-mining migrants in South Africa, but miners usually bring their earnings in cash and kind into Botswana. In 1976, Botswana citizens in the country earned P71.47 million, while the total earned by absentees in South Africa was estimated at about P68.99 million for $1976 / 1977.48$

\section{Conclusion}

Labour migration and its effects on the sending societies is one of those topics that have attracted a great deal of attention from researchers worldwide. In most studies, the crippling effects of labour migration on these sending communities has been given prominence, while the positive contributions have received cursory treatment. However, it is argued here that migrant labour has also contributed positively to the livelihoods of sending societies in the southern Botswana region by enabling migrants to make savings and invest in productive ventures such as transportation, general dealer businesses as well as agriculture. There is evidence that some migrants acquired vital skills - learning in the workplace, or as it is more commonly put, "on the job". In many cases, as is shown in the testimonies discussed above, they practised these same skills in Botswana after leaving South Africa. Others built magnificent houses and have employed a number of workers in their business enterprises.

\section{REFERENCES}

Adepoju, A., "Internal and International Migration within Africa", in Oucho, J. et al., Migration in South and Southern Africa: Dynamics and Determinants (HSRC Press, Pretoria, 2006).

Beinart, W., "Labour Migrancy and Rural Production: Pondoland c.1900-1950", in Mayer, P. (ed.), Black Villagers in an Industrial Society (OUP, Cape Town, 1980).

Bundy, C., "The Transkei Peasantry: Passing through a Period of Stress", in Parsons, N. and Palmer, R. (eds), The Roots of Rural Poverty in Central and Southern Africa (Heinemann, Los Angeles, 1977).

C. Kerven, C., "Botswana Mine Labour Migration to South Africa", in C. Kerven (ed.), National Migration Study (Central Statistics Office, Gaborone, 1979).

48. Kerven, "Botswana Mine Labour Migration to South Africa”, pp 16-19. 
Kerven, C., "Underdevelopment, Migration and Class Formation in the North East District of Botswana", PhD thesis, University of Toronto, 1977.

Kerven, C., Labour Migration and Agricultural Development in Botswana (FAO, Rome, 1987).

Kerven, C., "Introduction", in "National Migration Study", Paper Presented at a Workshop on Migration Research, Gaborone, 1979".

Kobokobo, K., "Labour Migration and its Economic Impact on the North East District: The Case of Bukalanga, 1870-1939", BA dissertation, University of Botswana, 1982.

Kowet, D., Land, Labour Migration and Politics in Southern Africa (The Scandinavian Institute of African Studies, Uppsala, 1978).

Kubanji, N., "The Impact of Labour Migration on the Tutume Sub-District: A Case of the Villages of Tutume, Sebina and Maitengwe", History Research Project, University of Botswana, 1992.

Leepile, M., "The Impact of Migrant Labour on the Economy of Kweneng, 1940-1980", BA dissertation, University of Botswana, 1981.

Letsatsi, R., "The Impact of Labour Migration on Botswana: A Case Study of Balete of Ramotswa, Bangwaketse of Kanye and Bakgatla of Mochudi, 1900-1970", BA dissertation, University of Botswana, 1984.

Maimbo, S. and Sander, C., "Migrant Labour Remittances in Africa: Reducing Obstacles to Developmental Contributions", Africa Regional Paper Series, No. 64, World Bank, Washington DC.

Massey, D., "Labour Migration and Rural Development in Botswana", PhD thesis, University of Boston, 1980.

Mgadla, P.T., "The Kgosi in a Traditional Setswana Setting", in Edge, W. and Lekorwe, M. (eds), Botswana: Politics and Society (J.L. van Schaik, Pretoria, 1998).

Morapedi, W., "Investments from Migrant Labour in Central Bukalanga of the Central District of Botswana, 1934-1985", Botswana Notes and Records, 44 (2012).

Morapedi, W. "Migrant Labour and the Peasantries of Bechuanaland Protectorate, 1930-1966", Journal of Southern African Studies, 25, 2 (1999).

Morton, B., "A Social and Economic History of a Southern African Reserve: Ngamiland 1890-1966.", PhD thesis, Indiana University, 1996.

Moyo, N., "Migrant Labour and Underdevelopment in Southern Africa: The Case of Botswana, Lesotho and Swaziland", Unpublished paper at Southern African Conference on Development and Politics of Liberation, University of Zambia, 1978.

Murray, D., Divided Families: The Impact of Migrant Labour in Lesotho (Cambridge University Press, Cambridge, 1981).

Parson, J., Botswana: Liberal Democracy and the Labour Reserve in Southern Africa (Lynne Reinner Publishers, Boulder, 1984).

Penny, N., Migrant Labour and the South African Gold Mining Industry: A Study of Remittances (UCT, School of Economics, n.d.)

Picard, L., Botswana: Liberal Democracy and the Labour Reserve in Southern Africa (Westview Press, Boulder, 1984).

Schapera, I., Migrant Labour and Tribal Life: A Study of Conditions in the Bechuanaland Protectorate (Heinemann, London, 1947). 
Solway, J., "Socio-economic Effects of Labour Migration in Western Kweneng", in Kerven, C. (ed.), National Migration Study (Government Printer, Gaborone, 1979).

Stitcher, S., Migrant Labourers (Cambridge University Press, Cambridge, 1985).

Taylor, J., "Mine Labour Migration from Botswana to South Africa.", PhD thesis, University of Liverpool, 1979

Taylor, J., "The New Economics of Labour Migration and the Role of Remittances in the Migration Process", International Migration, 37, 1 (1999).

Wentzel, M. and Tlabela, K., "Historical Background to South African Migration", in Oucho, J. et al., Migration in South and Southern Africa: Dynamics and Determinants (HSRC Press, Pretoria, 2006).

Whiteside, A., Some Aspects of Labour Relations between the Republic of South Africa and Neighbouring States: Part II, Economic Implications (HSRC Press, Pretoria, 1986). 